INTERNATIONAL JOURNAL OF RESEARCHES IN BIOSCIENCES, AGRICULTURE AND TECHNOLOGY (c) VISHWASHANTI MULTIPURPOSE SOCIETY (Global Peace Multipurpose Society) R. No. MH-659/13(N) www.vmsindia.org

\title{
EFFECT OF CHEMICAL AND MECHANICAL SCARIFICATION ON GERMINATION OF LATHYRUS SEEDS
}

Rajesh D. Gadewar ${ }^{1}$, Vandana S. Madke ${ }^{2}$ and Vipin B. Babhulkar ${ }^{3}$

${ }^{1}$ Sewadal Mahila Mahavidyalay and Research Academy, Nagpur.

${ }^{2}$ De partment of Botany, College of Agriculture, Nagpur.

${ }^{3}$ De partment of Agril. Chemistry, College of Agriculture, Nagpur.

\section{ABSTRACT}

Five genotypes of Lathyrus we re sown during 2015. The seeds after harvesting, threshing and processing we re evaluated for their hardseedness dormancy. The findings of the present study indicate that concentrated sulphuric acid, hot water, sand scarification and hot air oven methods are effective for reducing hardseedness in Lathyrus. All the above mentioned treatments showed injuries effect to the seed e mbryo by increasing the dead seeds and abnormal seedlings except concentrated sulphuric acid treatment. In general concentrated sulphuric acid tre atment for seconds have been found most effective for breaking seeds coat dormancy and also significantly highest germination pe rcentage compared to the above mentioned treatments undertaken in the present investigation.

Keywords: Lathyrus, dormancy, hardseed coat, germination, seedling vigour, field emergence.

\section{INTRODUCTION}

Seed dormancy is defined as the state in which seed are prevented from germination even under favorable conditions for germination. The impermeability of seed coat to wate $r$ is typical example of exogenability are known as hard seeds. This impermeability may be due to the presence of a cuticle and a well de veloped layer of palisade cells or both. Cutin deposits have been reported by Thronton (1968). The developme nt of hard seed has been reported to be influe nced both by genotypic and environmental factors (Puri and Laudlaw, 1984).

Most of the legume crop plants produce hard seeds to varying percentages. Most workers have found this trait to be heritable. However, the available lite rature does not clearly state the developmental stage in which the seed develops into hard seed. Hardseedness in Lathyrus creates problems in testing for ge rminability under laboratory conditions. Due to this state of affair, there is a great problem under field condition in securing uniform ge rmination and good crop stand for maximum crop production. The present study was undertaken to evaluate the methods to overcome hardseedness in Lathyrus (Lathyrus sativus $L$.)

\section{MATERIALS AND METHODS}

Five genotypes of Lathyrus viz., Ratan, Prateek, Mahateovra, Pusa-24 and Nirmal were used in the various phases of this study, produced in Kharif, 2015. Hard seeds which did not imbibe water. To evolve a quick method for breaking hardseedness in five genotypes of Lathyrus, the hard seeds were subjected to concentrated sulphuric acid ( 60 and 90 seconds), hot water $\left(100^{\circ} \mathrm{C}\right.$ for 180 and 240 seconds), sand scarification $\left(100^{\circ} \mathrm{C}\right.$ for 15 and 30 seconds).
For germination test in laboratory, the germination medium used was rolled towels paper under controlled conditions (i.e. temperature at $25 \pm 2^{\circ} \mathrm{C}$ constant and relative humidity $85 \%$ ), For acid treatment, the Lathyrus seeds were soaked in concentrated sulpuric acid for the specified duration with constant stirrings (Dharmalingam et al. 1973). Seeds were thoroughly washed in running water after the acid treatme nt and the germination was tested in quadruplicate with 100 seed in each replication. The ge rmination count was taken on the $8^{\text {th }}$ day and ge rmination pe rcentage was recorded on the basis of normal seedlings (ISTA, 1985).

\section{RESULT AND DISCUSSION}

The data for the five genotypes of Lathyrus tested for different methods of bre aking the hardseedness are presented in Table 1 . The ove rall comparisons of mean among and within genotypes and treatments for both normal seedling and hard seed per centage showed that concentrated sulphuric acid for 60 seconds was the most effective treatment for reducing hard seed content. It was followed by hotwater for 180 seconds sand scarification for 480 seconds, hot water 120 seconds, hot air oven 30 seconds, sand scarification 240 seconds, concentrated sulphuric acid of 30 seconds and hot air oven 15 seconds. All the treatments showed injurious effect by increasing the abnormal seedling except concentrated sulphuric acid for 60 seconds. There is no germination in control (untreated) seeds Duran and Tortosa (1985) has clearly explained the effect of concentrated sulphuric acid on seed coat of Sinapsis aruensis and conclude that it was the rapid dessication produced by concentrated sulphuric acid and not its hydrolytic capacity which seems to cause fragmentation of integuments and thus allowing 
the passage of water to the embryo. A similar mode of action can also be proposed for the response shown as Lathyrus ge notypes to the treatme nt with sulphuric acid.

\section{CONCLUSIONS}

The results obtained in the present investigation indicate that concentrated sulphuric acid treatment for 60 second has been found most effective for breaking hard seed coat dormancy in Lathyrus. The result confirms the finding of Charjan and Tarar (1990), Sing and Tomer (1993) and Cherian et. al. (2011).

Effectivness of concentrated sulphuric acid, hot water and hot air oven treatment for breaking harseedness was also reported in related crops by Borikar et. al. (1985), Radhakrishnan et al. (1989), Rana and Nautiyal (1989), Tomer and Maguire (1989), Verma and Sing (1989), Charjan and Tarar (1990), Sing and Tomar (1993) and Cherian et al. (2011).

Table 1 : Effect of different treatments on Germinability of Lathyrus

\begin{tabular}{|c|c|c|c|c|c|c|c|c|c|c|c|c|c|c|c|c|}
\hline \multirow[t]{2}{*}{ S. N. } & \multicolumn{2}{|c|}{ Treatments } & \multicolumn{3}{|c|}{ Ratan } & \multicolumn{3}{|c|}{ Prateek } & \multicolumn{2}{|c|}{ Mahateora } & \multicolumn{6}{|c|}{$\begin{array}{|ll|}\text { Pusa-24 } & \text { Nirmal } \\
\end{array}$} \\
\hline & & & $\mathrm{N}$ & $\mathrm{Ab}$ & $\mathrm{H}$ & \begin{tabular}{|l|l|l}
$\mathrm{N}$ & $t$ \\
\end{tabular} & $\mathrm{Ab}$ & $\mathrm{H}$ & $\begin{array}{ll}\mathrm{N} & \mathrm{Al}\end{array}$ & $\mathrm{H}$ & $\mathrm{N}$ & $\mathrm{Ab}$ & $\mathrm{H}$ & $\mathrm{N}$ & $\mathrm{Ab}$ & $\mathrm{H}$ \\
\hline 1. & Contro & treated hard seeds) & 0 & 0 & 100 & \begin{tabular}{l|c}
0 & 0
\end{tabular} & 0 & 100 & $\begin{array}{|ll|}0 & 0\end{array}$ & 100 & 0 & 0 & 100 & 0 & 0 & 100 \\
\hline \multirow[t]{3}{*}{2.} & \multicolumn{2}{|c|}{ Conce ntrated sulphuric acid } & & & & & & & & & & & & & & \\
\hline & i) & 30 seconds & 80 & 3 & 17 & 875 & 5 & 8 & 884 & 12 & 82 & 6 & 12 & 80 & 9 & 11 \\
\hline & ii) & 60 seconds & 98 & 2 & 0 & \begin{tabular}{|l|l|}
98 & 2 \\
\end{tabular} & 2 & 0 & 964 & 0 & 94 & 6 & 0 & 915 & 9 & 0 \\
\hline \multirow[t]{3}{*}{3.} & \multicolumn{2}{|c|}{ Hot water treatment $\left(100^{\circ} \mathrm{C}\right)$} & & & & & & & & & & & & & & \\
\hline & & 120 seconds & 80 & 2 & 18 & 816 & 6 & 13 & 828 & 10 & 83 & 5 & 12 & 80 & 4 & 16 \\
\hline & & 180 seconds & 89 & 2 & 9 & $90[5$ & 5 & 5 & 928 & 0 & 93 & 7 & 0 & 88 & 6 & 6 \\
\hline \multirow[t]{3}{*}{4.} & \multicolumn{2}{|c|}{ Sand scarification $\left(100^{\circ} \mathrm{C}\right)$} & & & & & & & & & & & & & & \\
\hline & i) & 240 seconds & 75 & 6 & 19 & 715 & 5 & 24 & 764 & 20 & 72 & 3 & 25 & 75 & 5 & 20 \\
\hline & ii) & 480 seconds & 88 & 2 & 10 & 90 & 2 & 8 & 922 & 6 & 93 & 4 & 3 & 912 & 2 & 7 \\
\hline \multirow[t]{3}{*}{5.} & \multicolumn{2}{|c|}{ Hot air oven $\left(140^{\circ} \mathrm{C}\right)$} & & & & & & & & & & & & & & \\
\hline & i) & 15 seconds & 62 & 6 & 32 & $68<$ & 4 & 28 & 655 & 30 & 66 & 4 & 30 & 642 & 4 & 32 \\
\hline & ii) & 30 seconds & 84 & 4 & 12 & $88[2$ & 2 & 10 & 865 & 9 & 89 & 3 & 8 & 88 & 3 & 9 \\
\hline
\end{tabular}

\section{REF ERENCES}

Borikar, S. T., Singh, A.R. and Katkade, J. L. 1985. Effect of pre treatme nt of greengtam (vigna radiata) seed with certain chemicals on its ge rmination, seed res. 13(1):192-194.

Charjan, S. K. U. and Tarar, J. L.1990. Methods to overcome hardseedness in soybean (Glycine $\max L$.) New Agriculturist 1 (1) : 7 1-74.

Che rian S., Lambat A., Gadewar R., Bhandari P., Charjan S., Lambat P. 2011. Postharvest dormancy in mungbean and their methods to overcome. Proceeding of Inte rnational Conference in Agricultural Engineering held at Chonburi, Thailand on dated 31 March -1 April 2011.

Dharmalingan, C., Madhavrao, S and Sunderaraj, D. 1973. Pregermination treatment of testing te sting seeds (Tephrosa purpures pers.) to improve germination. Seeds research. 1: 58 62 .

Duran, J.M. and Tortosa, M.E. 1985. The effect of mechanical and chemical scarification on ge rmination of Charlok (Sinapsis arvensis L.) seds, Seeds Science and Technology. 13:155163.

ISTA, 1985. International rules for seeds testing. Seed Science and Technology. 13: 299-513.
Puri, K. P. and Laudlow, A. S. 1984. The effect of temperature on components of seed yield and seed quality of hard red winter wheat from production field. J. App. Seed Production. 2 : 1823.

Radhakrishnan, J., Mahadevoppa, M., Joshi, S. and Prasad, T. G. 1989. Dormancy studies in Cassia sericae, Seeds Research. 17 (2) : 118-121.

Rana, U.,and Nautiyal, A. R. 1989. Coat imposed dormany in Acacia Famesiana seeds. Seeds Research. 17 (2) : 122.

Singh, K.J. and Tomer, R. P. S. 1993 Sudies on hard seeds in black-gram (Vigna mungo (L). Heper, Seeds Research. Special Vol. 2 : 919-923.

Thornton, M. L. 1968. Seed dormancy in watermelon. Proceedings Association Official Seed Analyssts. 58: 80-84.

Tomer, RPS and Maguire, J. D. 1989. Hard seed studies in alfalfa. Seeds Research. 17 (1) : 29-31.

Verma, O. P. and Sing, P. V., 1989. Methods to overcome hardseedness in Mungbea. Seeds Reaerch. 17 (20) : 197-198. 